Mediating citizenship through the lens of consumerism:

Frames in the American Medicare reform debates of 2003-2004

By: Emily West

This is an electronic version of an article published in Social Semiotics, Volume 16, Number 2, pp.243-261, June 2006.. Social Semiotics is available online at:

http://web.ebscohost.com/ehost/pdf?vid=2\&hid=108\&sid=02be2eea-919b-4da3-8598$\underline{33 \mathrm{~d} 0 \mathrm{e} 091299 \mathrm{~b} \% 40 \text { sessionmgr111 }}$ 


\title{
Mediating citizenship through the lens of consumerism: Frames in the American Medicare reform debates of 2003-2004
}

\author{
By: Emily West
}

\begin{abstract}
:
Access to health care is an issue that challenges the imagined boundary between being a 'consumer' and being a 'citizen'. This is especially true in the United States where marketbased solutions to providing health care have historically been favored over care organized through government. In the recent debate over how to organize prescription drug coverage for seniors in the United States, stakeholders quoted in the press were more likely to position health care as a consumer issue rather than as an issue of basic rights that accompany citizenship. As scholars such as Lizabeth Cohen (2003) have illustrated, being a 'consumer' is not necessarily a depoliticizing stance. Organizing around consumer rights can be effective in changing policy and bringing people together politically. However, discourse that remains within a consumer rights frame can also reinforce the terms of debate laid out by interested corporations and government. This paper looks at the 'consumer' and 'citizenship' frames in the 2003-2004 debate about prescription drug coverage for seniors in print and television news compared to those promoted by institutional sources. Proponents of the bill sold it on the basis of individualized consumer choice, implicitly collapsing the power of individual choices in both consumerism and citizenship. Compared to their institutional sources, the news media more often highlighted collective models of power and occasionally even resisted the frame of individualized consumerism promoted by supporters of the bill.
\end{abstract}

Key Words:

Choice, Citizenship, Consumerism, Framing, Health care, News analysis 
Access to health care is an issue that challenges the imagined boundary between being a 'consumer' and being a 'citizen'. This is especially true in the United States where health care co-ordinated through the market has historically been favored over care organized through government. The recent debate over how to organize a new prescription drug benefit for senior citizens in the United States illustrates how the various stakeholders in this issue - policymakers, drug companies, and advocacy groups - position health care as a consumer issue rather than as an issue of basic rights that accompany citizenship. It therefore serves as a timely case study of how the consumer identity is represented in the American public sphere, and how that identity intersects with politics.

The 2003-2004 debates about what kind of prescription drug benefit to add to Medicare, the government program that pays for many health costs of retirees, were consistent with the history of debates about health care in the United States (Gordon 2003, Tomes 2001). Employers, politicians, insurance companies, hospitals, the American Medical Association and others have consistently been successful in positioning health care as a consumer product or service rather than as a right of citizenship (Gordon 2003, Tomes 2001). While government does provide a minimum level of coverage for the indigent and disabled (through a program called Medicaid) as well as for veterans, health care for the vast majority is conceptualized as a service that falls within the individual's responsibility to prepare for. However, the system of privatized health insurance, in combination with rising costs due to technological and pharmaceutical advances in medical care, have made insurance premiums, co-pays, and deductibles unaffordable for many people, especially those who are self-employed, do not have access to insurance through their employer, or who have pre-existing conditions that lead insurance carriers to raise premiums to discourage them from enrolling. While countries all over the world are currently struggling with how to keep 
up with spiraling health care costs for their citizens, in the United States, where Americans pay as much as twice per capita as their industrialized peers but have been ranked $37^{\text {th }}$ on the quality of their health care system by the World Health Organization, the situation is particularly dire (World Health Organization 2000, Nightline - ABC 2003). In short, marketbased health care is a system defined by inequality.

In his work on the history of health care policy debates in America, Colin Gordon (2003: 10) draws attention to the consistency with which the 'contributory principle' has prevailed, which is the belief that people will only value their health care (and therefore use it responsibly) if they have directly contributed through premiums or other payments to its delivery -- a consumer model of virtue. As a result, the American health care system favors not only an insurance based system, but increasingly one with co-pays and deductibles, so that recipients of care never feel like it is 'free', but that they directly pay in some way for the care they are getting. Generally, those who receive their health care through taxes rather than through a system of privatized insurance are viewed as recipients of charity whose care must be carefully monitored to prevent abuses. The exception to this rule is Medicare, a government program passed in 1965 for senior citizens that covers hospital and in-patient services and provides an optional insurance program for doctors' visits and other out-patient services (Gordon 2003). It is one of the few government programs that the American public views with goodwill. However, as people live longer and medical care depends more on prescription drugs, the costs of which have been rising steadily, the lack of a prescription drug benefit has become a political liability for both parties.

In early 2003 the Bush Administration made Medicare reform, and the addition of a prescription drug benefit in particular, a high priority. By 8 December 2003 the Medicare Prescription Drug, Improvement, and Modernization Act was signed by President Bush 
(KFF 2005). The prescription drug benefit, slated to begin January 2006, promises estimated discounts of one-third to less than half the average senior citizen's drug costs (World News Tonight-ABC 2003a). ${ }^{\mathrm{i}}$ The benefit is funded by, but not administered through Medicare. Seniors have the option of staying in regular Medicare for other services and enrolling in a drug benefit through a participating company, or having all their benefits coordinated through a private insurance company, subsidized by Medicare (KFF 2005).

Lewis, Wahl-Jorgensen and Inthorn (2004) argue for the importance of representations of citizenship in mass media and through content analysis demonstrate that, in both American and British news, citizens are represented as more passive than engaged. As consumerism becomes more prominent, and as citizenship appears to be on the decline with reduced voting rates, political knowledge, and community involvement (Putnam 2000, Cappella and Jamieson 1997), it is important to understand how the role of consumer and citizen are conceptually related in the American public sphere. The role of consumer has a great deal of cultural resonance, perhaps increasingly so as growing spending power and commercialism in industrialized nations lead people to more often be positioned as consumers relative to other kinds of roles. Throughout the prescription drug debates, users of the system were not often represented as citizens who must share in these difficult decisions, but as consumers of the health care system, providing a case study of how the responsibilities and rights of citizens can become subsumed by the rhetoric of consumerism.

As Lizabeth Cohen (2003) and T.H. Breen (2004) have illustrated through their historical scholarship, being a 'consumer' is not necessarily antithetical to the role of citizen, despite popular images of consumers as self-interested, even selfish utility maximizers and citizens as community-minded co-operators. T.H. Breen (2004) provocatively argues that in colonial times the American consumer experience sowed the seeds of future political 
cooperation in the revolution. Ordinary people experienced their own political power for the first time when they worked with other colonists to put political pressure on the British through boycotts of their imported goods.

While Breen (2004) traces an American consumer politics back to colonial times, Cohen (2003) describes the consumer politics of the $20^{\text {th }}$ century. Cohen $(2003,8,44)$ suggests the 'citizen consumer' puts 'the market power of the consumer to work politically' for the common good, as exemplified by Progressive Era reformers who used consumer boycotts and reform organizations to bring about product safety regulations, or by AfricanAmerican consumers in 'Don't Buy Where You Can't Work' campaigns during the Depression. In contrast, the 'purchaser consumer' engages in 'the pursuit of self-interest in the marketplace out of confidence in the ameliorative effects of aggregate purchasing power', such as boycotts of meat organized by women in the 1930s to bring about more affordable prices (Cohen 2003: 8, 36). In both categories, people organize as consumers in political ways to bring about collectively desired ends, be they political or economic in nature.

Despite the political potential in the consumer role, this paper argues that there are times when discourse that remains within a consumer rights frame reinforces the terms of debate laid out by interested corporations and government, thereby disempowering people both as citizens and consumers. This study examines the 'consumer' frame in the debates about prescription drug coverage for seniors in policy discourse and US print and television news. The consumer frame dominated the policy discourse, with surprisingly few appeals to the rights or powers of citizens even from groups that positioned themselves as reformers of American health care and advocates of health system users. The case study shows how the 
frame of consumerism individualized this health care policy issue, rather than encouraging people to think of themselves as part of a collectivity.

The concept of consumer choice was central in crafting and selling the Medicare prescription drug benefit. 'Choice' was often conflated with empowerment, freedom, and ideals of democratic citizenship. In order to undermine the magic of 'choice' offered by the bill's proponents, critics tried to deconstruct the taken-for-granted notion that more choice equals better outcomes. Overall though, the consumer frame was not so much opposed as critiqued from within. Wholesale challenges to the idea that health care is a consumer issue were more common in the news media than among institutional critics such as the AARP and Families USA. The citizen was sometimes introduced in mass media coverage as a counterpoint to the health care consumer, allowing the news media to raise issues left completely unaddressed by the discourse of consumerism.

\section{Methodology}

Framing is an inescapable aspect of communication, in that selecting and excluding information, and providing some kind of emphasis or meaning system within which facts can be interpreted is essentially unavoidable (Pan and Kozicki 2001). However, scholars of news and politics note how strategically political issues are often framed by stakeholders. Researchers recognize that media frames are often the result of struggle among the groups that serve as sources, and that these competing frames are ultimately arguments about the meaning of an issue and what its outcome in terms of policy should be (Gamson 2001, 1992, Richardson and Lancendorfer 2004).

This study takes guidance from William Gamson's framing research in Talking Politics (1992: 3) in which he and his team initially identified the frames, or 'implicit organizing 
ideas', being used by the shapers of political issues in their policy documents, press releases, and other publications. To this end, documents relevant to the Medicare reform issue found in the online archives of the following organizations were examined:

- AARP (American Association for Retired Persons) - a powerful lobby whose eventual approval the legislation is widely thought to have depended upon

- AHIP (America's Health Insurance Plans) - a trade association representing 1300 companies that provide health insurance

- AMA (American Medical Association) - the largest professional association representing America's physicians

- Families USA - a reform-minded nonprofit, advocacy organization that describes itself as 'the voice for health care consumers' (www.familiesusa.org)

- PhRMA (Pharmaceutical Research and Manufacturers of America) - the pharmaceutical industry trade association.

In total, 116 documents were studied to examine the terms of debate and disagreements most common among those closest to the Medicare prescription drug issue.

The themes presented in the source documents were then compared to how the issue appeared in mainstream media outlets, taking inspiration from Gamson's approach of seeing how 'culturally available' frames are reproduced, and even challenged, in the news media (1992: 215). Three outlets were chosen: the national daily newspaper USA Today, ABC television news (a major broadcast network), and both broadcast and online CNN news (a major cable network). The terms 'prescription drug' and 'coverage' were used as search terms in the Lexis-Nexis database in the headline/lead paragraph, yielding 95 relevant media documents from 2003-2004. ${ }^{\text {ii }}$

One of the $\mathrm{ABC}$ documents found in the Lexis-Nexis search was part of a week-long series of in-depth reports in October 2003 called Critical Condition. The rest of the series was collected to see how ABC used the opportunity presented by the Medicare reform debates to address health care policy more generally. Critical Condition arguably also represents a 'thematic' news frame that Iyengar (1991: 2) has contrasted with the 'episodic' frame in his 
research. Iyengar (1991) argues that more event-oriented episodic coverage tends to individualize political issues whereas thematic coverage, which is more abstract and seeks to summarize and analyze an issue, encourages audiences to attribute societal responsibility for both causes and solutions.

All documents were analyzed using N-Vivo qualitative research software. Analysis of the documents yielded 'nodes' or themes of relevance that could then be reviewed to check for consistency and to compare how these themes were treated by different sources. Although tracking word choices does not exhaust frame analysis and is only suggestive of the assumptions and meaning systems that underlie them, scholars have found the comparison of word counts a useful strategy in illustrating the relative prevalence of frames across sources and publications (Entman 1993, Miller and Reicher 2001, Bantimaroudis and Ban 2001). An examination of word choice across the different textual sources complemented the qualitative textual analysis.

\section{Bowing to the Altar of Consumer Choice: How the Medicare Prescription Drug Benefit was Sold}

The Bush Administration 'sold' the Medicare prescription drug benefit in 2003 by hanging its pitch primarily on the principle of consumer choice. In his June 2003 speech Bush said, 'The centerpiece of this approach is choice' (CNN 2003a), and in November of 2003, Bush argued in his weekly radio address, 'With choice, seniors would have more control over their health care options, and health plans would compete for the business with better coverage' (CNN 2003b). He portrayed 'choice' as a route to empowerment, not only over one's own destiny but also as a way of exerting power over the market, forcing it to compete and provide ever better benefits for the carefully guarded health care consumer's dollar. Bush's complete faith in the market to produce optimal results for individuals is 
illustrated in his December 2003 statement after the bill passed: 'For the seniors of America more choices and more control will mean better health care' (CNN 2003c). Bush also explained how the principle of individual choice embedded in the Medicare reform legislation fit with his broader philosophy, saying 'We are putting individuals in charge of their health care decisions. And as we move to modernize and reform other programs of this government, we will always trust individuals and their decisions and put personal choice at the heart of our efforts' (CNN 2003c).

Industry supporters such as AHIP and PhRMA also presented more 'choice' as unambiguously good for beneficiaries of the bill, implicitly equating 'choice' with control, empowerment, and rights. About the administration's new plan, President and CEO of PhRMA (Pharmaceutical and Research Manufacturers of America) Alan Holmer opined, 'This is competition and consumer choice in action, giving seniors the information they need to make informed choices, and negotiating real savings on prescription drugs for them' (PhRMA 2004a). AHIP (America's Health Insurance Plans) President and CEO Karen Ignagni referred to the bill as the 'drug and choice legislation' (AHIP 2003c), and a number of AHIP press releases promoted a 'grassroots' campaign ('Members of the Coalition for Medicare Choices') that urged Congress to pass Medicare reform (e.g. AHIP 2003b). Bush argued that, 'If choice is good enough for lawmakers, it is good enough for America's seniors' (CNN 2003a), and AHIP reinforced his point with an outdoor ad campaign that read, 'Congress has choices in health care. America's seniors should, too' (AHIP 2003a). The exact nature of the choices involved remained vague, but what remained was the positive feeling that surrounds the principle of individual choice in American culture.

Individual choice arguably lies at the heart of both the consumer and citizen identities or roles, a connection that the proponents of the Medicare Modernization Bill took 
advantage of. A central ritual of citizen power, voting, involves the exercise of choice, and in a sense consumers 'vote' with their wallets when they purchase goods and services. The Bush Administration and its supporters encouraged observers to focus on its vindication of personal choice as a proxy for individual empowerment, thereby creating a democratic halo effect for the legislation.

Presenting the roles of citizen and consumer as functionally equivalent is neither new nor unique to the US health care debate. Cohen (2003: 8-9) argues that while the 'citizen consumer' and 'purchaser consumer' models of engagement were prominent in the early to mid-20 $0^{\text {th }}$ century, post WWII saw the rise of the 'purchaser-as-citizen' mode of consumer politics, in which Americans increasingly believed that individual consumers maximizing their self-interest would bring about the best result for the whole society, through the mechanisms of the free market. The White House embraced this vision of citizenship when they encouraged people to shop, buy domestic cars and take vacations as their contributions to the fight against terrorism after the attacks of September 11 ${ }^{\text {th }}, 2001$ (Cohen 2003). In the growing prominence of the 'what's in it for me' approach to electoral politics, Cohen (2003: 9) argues we see a newly combined consumer/citizen/taxpayer/voter identity in which the primacy of self-interest collapses any distinctions between these roles. By encouraging Americans to see the most important mode of exercising power and 'control' in their consumer choices, the arguments in favor of the Medicare prescription drug benefit strengthened and reinforced the appropriateness of a consumer mentality when it comes to both health care delivery and government.

While supporters of the bill celebrated the 'control' that health care consumers would now have, one of the most important reasons for having consumer choice in health care, both for this bill and historically, is the belief that the 'contributory principle' will 
discipline consumers who otherwise, it is assumed, will be tempted to overuse and abuse their health care benefits (Gordon 2003). Belief in this principle shines through in the following passage from an AHIP publication:

We have learned through experience that it is not simply the personal medical account or high-deductible insurance plan that saves the money, it is the change in consumer lifestyles and smarter health care shopping habits that come only through the proactive application of education and incentives. (Spiker 2004: 51)

Similarly, in a public speech PhRMA's CEO said that the Medicare prescription drug benefit, 'offers consumers a choice among private health plans. That takes me to market-based cost containment, the second part of affordable access' (PhRMA 2003). The mainstream news media picked up on the disciplinary motivation behind the push for 'consumer choice'. For example, USA Today mentioned, in a number of different articles, statements to the effect that, 'Bush ... wants more Americans to shop for their insurance coverage or medical services, reasoning that if they are more attuned to the costs, market forces will limit health care inflation' (Welch 2004). What was pitched as pure freedom, power and control was in fact a mechanism for users of the health care system to control their own consumption - to be limited by the stretch of their wallets in paying premiums, deductibles, and the costs of drugs. While the legislation specifically allowed drug companies and health insurance plans the freedom to set the costs of drugs and forbade government from negotiating better prices, it placed faith in the mechanisms of the market to discipline consumers.

\section{Questioning the Primacy of Consumer 'Choice': The Critics Respond}

The emphasis on 'choice' in the pro-Medicare reform camp automatically positioned opponents of the bill as 'anti-choice', and therefore as anti-democratic. Critics like the AARP and Families USA had to tread carefully so as not to come across as the enemies of individual freedom, while trying to neutralize the rhetorical magic of 'choice'. 
Families USA pointed out that the endless mantra of choice was vague and possibly misleading to seniors. Bush and other supporters of the bill did not mean choice of doctor, hospital, or brand of drug. Rather, they were referring to seniors' choice of which insurance or managed care company would administer their prescription drug benefit. Ironically, the 'choice' of insurance provider could lead to less choice on substantive questions of carewhich doctor, which hospital, and which drugs the patient would have access to (Families USA 2003a).

A second strategy questioned the promotion of 'choice' as the sole criterion for evaluating the benefit to health care consumers, suggesting access, affordability, and quality as other important considerations. Families USA returned again and again to the question of affordability, questioning whether the 'choices' supplied by the bill would actually result in meaningful savings on drug costs for seniors. Similarly the AARP kept affordability squarely at the center of their concerns about the bill. In a list of their members' top concerns, the question of choice did not appear at all; instead, they were listed as:

Access to coverage for everyone in Medicare Affordable out-of-pocket costs Gaps in coverage kept to an absolute minimum Reasonable and affordable cost sharing Protection from continuing rises in already-high drug costs (AARP 2003a)

The AARP ended a number of press releases with the statement, 'AARP will continue to work in Washington, in the states and in other ways to make drug costs more affordable and accessible' (e.g. AARP 2003b), signaling that despite their eventual endorsement of the bill, fighting for drug affordability remained their top priority, rather than the principle of consumer choice.

The heart of disagreements about the 2003 Medicare Modernization Act centered on the role of the private sector in managing health care delivery, and whether the private sector 
would produce the efficiency and cost containment necessary for seniors to afford their prescription drugs. Critics of the plan tried to plant seeds of doubt about whether the private sector could deliver true affordability, pointing to past and present failures. A specific example they often raised was the lackluster performance of an existing program called Medicare+Choice, in which Medicare is administered through private insurance companies. Critics also pointed to the lack of evidence that free market arrangements are effective for health care in general. In comparison to the apparent success and user satisfaction with the few government-financed health care programs in the US (Medicare and health care administered by the Veterans Administration), care organized through private health insurance companies and Health Maintenance Organisations (HMOs), does not appear to have significantly controlled costs (Barry 2003). While Medicare has a very large bargaining unit to bring to the table, the 2003 legislation specifically prohibited the government from bargaining with drug companies for lower prescription drug costs (Vaughan 2003). Ron Pollack, executive director of Families USA, complained that while the designers of the Medicare drug benefit 'dole out huge subsidies for HMOs, Preferred Provider Organizations (PPOs), and drug companies, Congress should make sure that the people who need help the most actually receive it' (Families USA 2003b).

The final critique of the bill as a vindication of 'consumer choice' questioned the basic logic that more choices would equal better outcomes for Medicare recipients. While ideals of the 'rational consumer' posit that consumers can gather information about all their different options and then choose the option that will deliver the optimal benefit (Schor 2000), the 'choices' made possible by the Medicare Modernization bill seemed likely to escape this consumer logic, in part because of the limited abilities of seniors themselves to understand their options, and in part because of the nature of the choices they would be 
confronted with. Many observers as well as individual seniors expressed reservations about the complexity of the benefit and the difficulty for both seniors and their caregivers to figure out which option would allow them to get the drugs they needed while saving them the most money. An AARP web article reported widespread confusion with the discount card program, put in place until the full benefit begins in January 2006. Even those with access to the internet reported the research process to be time-consuming and confusing (Barry 2004). In response to the complexity of the program, Families USA made a video and organized a traveling expo where seniors could go to learn about the benefit, ask questions, and receive some guidance on what discount card to choose (Families USA 2004). One obstacle was that seniors had to guess what their medical problems would likely be in determining which card best met their 'individual needs'. Further, the legislation allows Medicare recipients to change their benefit provider only once a year, while providers can change their drug prices and formularies on a weekly basis, making it difficult for users to predict what plan would yield the greatest savings. One study concluded that confusion and uncertainty about whether there would be actual savings were preventing Medicare recipients from enrolling in the program (KFF 2004).

Institutional critics of the Medicare Prescription Drug Improvement and Modernisation Act found a number of ways to counter the argument that the legislation vindicated consumer choice and empowerment. However, these critiques remained within the frame of consumerism established by the proponents of the bill. Rather than directly challenging the notion that health care is a consumer good, these critics questioned the primacy of 'choice' in determining what is best for the health care consumer, and questioned whether the choices supplied by the legislation were meaningful and would ultimately provide the savings promised by free market competition. While the opposition attacked 
many of the claims offered by the bill's proponents, they rarely attacked the fundamental assumption upon which the legislation rested - that health care is a consumer issue that concerns consumers as individuals.

\section{Media Coverage of the Prescription Drug Debates}

This paper argues that the framers of the prescription drug benefit discourse in 2003, both proponents and critics, represented it as an issue of consumerism rather than of citizenship. The word choices of the organizations that created these frames compared to those of the sampled mainstream media sources that reported on them also suggest this pattern. Table I summarizes word counts from the corpus of documents examined for this study, aiming to capture the labels that different sources chose to use for the people affected by the issue. Gamson (1992: 9) suggests that we pay attention to labels such as these, as they are 'frequently and appropriately...the target of symbolic contests between supporters of different ways of framing an issue domain'.iii The total number of documents for each source, as well as the incidence of each term per thousand words are included to facilitate comparison across texts from different sources. ${ }^{\text {iv }}$ 
Table I: Word Counts of Citizen, Consumer, and Patient from Institutional and Media $\underline{\text { Sources }}$

\begin{tabular}{|l|c|c|c|c|c|c|c|c|}
\hline $\begin{array}{l}\text { INSTITUTIONAL } \\
\text { SOURCE }\end{array}$ & $\begin{array}{c}\text { Citizen } \\
\text { Count }\end{array}$ & $\begin{array}{c}\text { Consumer } \\
\text { Count }\end{array}$ & $\begin{array}{c}\text { Patient } \\
\text { Count }\end{array}$ & $\begin{array}{c}\text { Total } \\
\text { documents }\end{array}$ & $\begin{array}{c}\text { Total Word } \\
\text { Count }\end{array}$ & $\begin{array}{c}\text { Citizen } \\
\mathbf{1 1 0 0 0}\end{array}$ & $\begin{array}{c}\text { Consumerl } \\
\mathbf{1 0 0 0}\end{array}$ & $\begin{array}{c}\text { Patient/ } \\
\mathbf{1 0 0 0}\end{array}$ \\
\hline AARP & 2 & 7 & 10 & 45 & 33,352 & 0.06 & 0.21 & 0.30 \\
\hline AHIP & 0 & 28 & 12 & 20 & 10,249 & 0 & 2.73 & 1.17 \\
\hline AMA & 0 & 0 & 17 & 7 & 2514 & 0 & 0 & 6.76 \\
\hline FUSA & 7 & 10 & 7 & 22 & 14,879 & 0.47 & 0.67 & 0.47 \\
\hline PhRMA & 0 & 6 & 92 & 13 & 7596 & 0 & 0.79 & 12.11 \\
\hline Bush speeches & 6 & 0 & 1 & 3 & 3853 & 1.56 & 0 & 0.26 \\
\hline & & & & & & & & \\
\hline $\begin{array}{l}\text { MEDIA } \\
\text { SOURCE }\end{array}$ & & & & & & & & \\
\hline ABC & 5 & 0 & 4 & 14 & 9120 & 0.55 & 0 & 0.44 \\
\hline $\begin{array}{l}\text { Critical } \\
\text { Condition }\end{array}$ & 3 & 4 & 21 & 12 & 13,138 & 0.23 & 0.30 & 1.60 \\
\hline $\begin{array}{l}\text { CNN \& } \\
\text { CNN.com }\end{array}$ & 6 & 0 & 6 & 33 & 21,571 & 0.28 & 0 & 0.28 \\
\hline USA Today & 17 & 6 & 34 & 48 & 34,144 & 0.50 & 0.18 & 1.00 \\
\hline
\end{tabular}

Table I shows that, other than the White House administration, institutional sources involved in the Medicare prescription drug debate defined it as an issue that affects people as 'consumers' or 'patients' but less often as 'citizens'. The frame-making organizations favored the use of the labels 'patients' or 'consumers' depending on their own orientation to the issue. For example, both the AMA and PhRMA may have favored the term 'patient' over 'consumer' because of how it linguistically maintains their authority as providers or prescribers of prescription drugs to determine what is best for 'patients', rather than having to follow the dictates of either government or private managed care plans. One PhRMA press release was headlined, 'New Research Shows Patients Need Choice of Medicines for Best 'Treatment' (PhRMA 2004b). In contrast, the Association of Health Insurance Plans favored the term 'consumer' over 'patient', thereby reinforcing their oft-repeated claim that all good outcomes grow out of consumers choosing from a range of private health plans. Even the critics of the plan, Families USA and AARP, described themselves as 'consumer' advocacy groups rather than citizens' organizations. 
In fact, it was the sampled mainstream media that used the word 'citizen' more consistently than any of the other organizations, with the exception of President Bush in his public speeches and other politicians who unsurprisingly consistently favored this term. Although Bush's rhetoric of choice and the free market came out of a discourse of consumerism, his speeches conspicuously referred to 'citizens' and not 'consumers', cementing the collapse of these two categories into one identity governed by individualized self-interest.

In contrast, the media organizations were more likely to talk about citizens and consumers in terms of organization and action. $\mathrm{ABC}, \mathrm{CNN}$, and USA Today invoked senior citizens as a group that was watching Washington carefully and would not hesitate to apply collective pressure to bring about desired ends. They described the AARP as a senior citizens' lobby, rather than a consumer group, and discussed how politicians were seeking to be responsive to this group of citizens who felt they deserved this government-funded benefit (e.g. CNN.com 2003, World News Tonight-ABC 2004). One USA Today news item even recalled the image from the 1980s of senior citizens rocking the car of a politician who had supported an unpopular plan for insuring catastrophic health costs (Welch 2003a). Further, when USA Today and ABC's Critical Condition used the term 'consumer', they were not portraying them as individuals empowered through choices. Out of the six instances where USA Today discussed 'consumers', three described consumers as the victims rather than the beneficiaries of the legislation, including one news report that highlighted how collective consumer empowerment had been prevented:

Pharmaceutical companies have averted what they feared most: a single new bloc of 40 million consumers with the market power to dramatically drive down prescription prices -- and industry profits. Both the House and Senate versions of the bill bar the government from getting involved in price negotiations. (Drinkard 2003) 
While the term 'consumer' did sometimes appear in media coverage, it was rarely in the positive, empowering light used by their sources.

Although the news media sometimes resisted the consumer frame through word choices, there were also instances where they directly challenged the notion of health care being solely a consumer issue through the substance of their stories. This occurred most notably on ABC's Critical Condition. In the course of this series questions were raised by reporters and those they interviewed that, if only briefly, effectively broke the frame of health care as purely a 'consumer issue'. For example, a cardiologist from Gary, Indiana complained, 'Patients are now called either clients or customers. That to me is unacceptable, and flies against what medicine is supposed to be about' (World News Tonight-ABC, 2003b). The following interaction between ABC anchor Peter Jennings and health policy commentator Dr. Tim Johnson also serves as an example:

JENNINGS: It is conventional wisdom that the rest of us pay for the uninsured. Do we or do we not?

JOHNSON: Well, ultimately, of course, somebody has to pay the bill. And it is often the taxpayer, both directly and indirectly. But I think we pay in ways other than money. We pay in terms of the increased poor health of people who are uninsured. Increased death rates. They also have a 10 percent to 30 percent less likely chance of producing income from a job. So we lose as a society. We lose medically, we lose financially. And I personally think we lose morally.

(World News Tonight-ABC 2003c)

These interactions introduced the idea that there might be moral considerations in the distribution of health care in society, a notion that did not appear so explicitly anywhere else in the source material.

USA Today published a commentary piece that made a similar point, saying that the goal of a Medicare prescription drug benefit should be combined with a commitment to organize some coverage for all the uninsured, thereby delivering 'a social good prized above all others: improved health for the whole American population, with less disease, illness, 
suffering and disability' (Findlay 2003). However, the history of health policy debates in the US is often the story of fragmentation among groups in society, or a 'divide and conquer' strategy that has effectively prevented any universal form of health insurance emerging (Gordon 2003). According to Gordon's historical account, men have been pitched against women, whites against blacks, unionized against non-unionized workers, and the insured against the uninsured. In general, 'deserving' consumers of health care benefits have consistently been encouraged to distinguish their means of accessing health care from nondeserving and dependent 'charity cases'. Pan and Kosicki (2001) argue that the strength of interest groups in American politics make any attempt at health care reform difficult, and that former President Clinton's attempt at reform in the early 1990s failed in part because he did not take these interest groups into account and work with them closely enough. As they put it, 'framing not only frames an issue but also frames social groups' (Pan and Kosicki 2001: 44), and the consumer frame tends to include those of a certain income and exclude those without the steady employment or disposable income that make them viable consumers in the health care market. While instances that broke the consumer frame were not the dominant mode of media coverage of the Medicare reform debates, they did introduce a collective stake in health care that was not part of the individualistic consumer frame used by the news media's sources.

The news media also appeared to linguistically resist the focus on 'choice' that was so common among the political and institutional proponents of the bill. Table II shows the counts and incidence per thousand words of the terms 'choice' and 'choices'. The bill's staunchest proponents, President Bush and AHIP, had the highest incidence of 'choice', followed by the AMA and PhRMA who were also supportive. AARP and Families USA used the word 'choice' much less often, and the media also at a relatively low rate. ${ }^{\mathrm{V}}$ Given 
the centrality of 'choice' in the administration's pitch for the prescription drug plan and the consistency with which supporters spread that message, the reduced incidence of the term in media coverage suggests that the frame was not simply swallowed whole in its representation.

$\underline{\text { Table II - Incidence of 'Choice' among Institutional and Media Sources }}$

\begin{tabular}{|c|c|c|c|c|}
\hline $\begin{array}{l}\text { INSTITUTIONAL } \\
\text { SOURCE }\end{array}$ & $\begin{array}{l}\text { Choice } \\
\text { Count }\end{array}$ & $\begin{array}{c}\text { Total } \\
\text { documents }\end{array}$ & $\begin{array}{c}\text { Total Word } \\
\text { Count }\end{array}$ & $\begin{array}{c}\text { Choice } \\
I 1000\end{array}$ \\
\hline AARP & 19 & 44 & 31,974 & 0.59 \\
\hline AHIP & 60 & 20 & 10,249 & 5.85 \\
\hline AMA & 4 & 7 & 2514 & 1.59 \\
\hline FUSA & 9 & 22 & 14,879 & 0.60 \\
\hline PhRMA & 12 & 13 & 7596 & 1.58 \\
\hline Bush speeches & 22 & 3 & 3853 & 5.71 \\
\hline \multicolumn{5}{|l|}{$\begin{array}{c}\text { MEDIA } \\
\text { SOURCE }\end{array}$} \\
\hline$A B C$ & 1 & 14 & 9120 & 0.11 \\
\hline $\begin{array}{c}\text { Critical } \\
\text { Condition }\end{array}$ & 6 & 12 & 13,138 & 0.46 \\
\hline $\begin{array}{c}\text { CNN \& } \\
\text { CNN.com }\end{array}$ & 12 & 33 & 21,571 & 0.56 \\
\hline USA Today & 16 & 48 & 34,144 & 0.47 \\
\hline
\end{tabular}

Despite the many ways that health care does not function like most consumer goods and services, the 'consumer frame' - which draws on so many American common-sense notions about individual choice and the desirability of free markets - remained dominant in this instance of health care policy discourse. News media have an opportunity to resist and counter the frames presented by sources, and it appears that to some extent they did so by invoking 'citizens' as well as 'consumers', and questioning the panacea of 'choice'. These counter-frames received more emphasis in 'thematic' coverage (Iyengar 1991: 2), particularly on the $\mathrm{ABC}$ series Critical Condition and in USA Today commentary pieces in comparison to the 'episodic' coverage of Washington speeches and press conferences that dominated on CNN. CNN devoted much of its coverage, both televised and online, to quoting the 
positions of politicians and covering the Congressional and Senate votes on the bill rather than providing independent explanation and commentary. In the routine reporting of news events it is understandably more difficult to introduce frame-breaking moments - a problem not unique to this issue but widespread in journalism due to its structural reliance on press releases, public relations, and official sources (Gandy 1982, Tuchman 1978). The will and resources to create a sustained investment in the health care story above and beyond reporting the facts of the current political controversy may be key to the creation of these frame-challenging moments.

\section{Empowering Consumers or Citizens?}

Many industrialized countries use the biggest bargaining unit of all, the nation's population, to spread risk and negotiate lower prices with providers of medical care and prescription drugs. These arrangements require some collective cooperation, and a belief that through this cooperation everyone will receive benefits on an individual level. This approach arguably represents the citizen consumer and/or purchaser consumer mindsets described by Cohen (2003). As citizen consumers, people can work together to ensure that their health care system will provide comprehensive coverage for all citizens (not just selected groups judged to be deserving recipients). As purchaser consumers, people can combine their spending power, or tax dollars, to discipline the market, bargaining for more reasonable prices on prescription drugs and medical services.

These approaches to consumer empowerment were not part of the plans for a Medicare prescription drug benefit in 2003. Rather than the collectivity of consumers using their power to discipline the health care market, the system invited individual consumers to choose among different insurance plans, ultimately a plan for the market to discipline 
consumers. The purchaser-as-citizen mindset, exemplified by the issue framing of the White House, AHIP, and PhRMA, encouraged people to think of their power in the arena of individual consumer choices, rather than through collective action.

Health care is not an ordinary commodity. As an 'undesired necessity' (Tomes 2003), people are in a poor position to boycott its purchase, or to make decisions independently of health care providers about what care or drugs they need. As the costs of health insurance and prescription drugs, let alone the cash value of actual care, grow beyond the means of even middle-class Americans, people find themselves vulnerable in the health care marketplace, unsure if their insurance or savings will see them through an extended old age, unexpected illness, or catastrophic accident. Opinion polls show that Americans are increasingly in favour of a single-payer or government-coordinated insurance program that would guarantee a minimum level of universal coverage, up to $62 \%$ in 2003 (ABC News/Washington Post 2003). And yet, those setting the health care agenda succeed in maintaining the frame around health care as a consumer issue.

It is tempting to decry uncategorically the notion of 'consumer empowerment', or fear that the role of citizen is becoming completely subsumed by that of consumer. However, Breen (2004) and Cohen (2003) remind us that the roles of citizen and consumer are not necessarily antithetical. And yet, positioning people as 'consumers' of health care or of other government policies can be depoliticizing, and the Medicare reform debates of 2003-2004 provide an example of this. While working within the consumer frame, it is difficult to combine the interests of the insured and uninsured, to encourage people to seek collective solutions, or to mobilize a discourse of human rights around health care. As historian Tomes (2001, Graph 48) writes, 'the politics of consumerism tend to privilege the interests of people with money to spend', leaving those without the requisite consumer 
power, that comes in the form of dollars, out of the equation. This inequality is certainly present in all consumer issues, but the stakes are different in the consumer politics of health care. If the poor are priced out of the transportation market, for example, it is a hardship, but if they are priced out of health care it can be a question of life and death.

The Medicare debates suggest that 'choice' is a magical word that deserves special attention because of how it communicates control and empowerment and associates the role of consumer with the powers and privileges of citizenship. In a recent op-ed in the New York Times, economist Paul Krugman (2005) describes how corporate lobbyists are using the rhetoric of 'choice' to combat anti-obesity campaigns, implying that negative health outcomes are only the result of individual, 'rational' consumer choices and therefore should not be challenged. Krugman (2005) suggests that a narrow focus on questions of individual choice in the market is an implicit argument for citizens and government to do nothing, leaving all social goals to the work of the invisible hand.

While consumer choices can certainly have an impact, a simplistic rhetoric of consumer choice is naïve when it comes to economics or politics. The truly 'free' market is hardly to be found, either in the realm of consumer products and services or of political ideas. The rhetoric of free markets and invisible hands exaggerates the 'freeness' of those things and obscures the considerable human engineering that usually goes into them. A vision of engagement that relies on individual choice discourages people from considering the history of the presented options, or thinking about possibilities outside of these options. The tendency of the news media to present passive modes of citizenship has been documented by Lewis, Wahl-Jorgensen and Inthorn (2004). This case study raises another layer of questions because the favored representation of engagement in this issue, consumer choice, has the veneer of active engagement and empowerment, but arguably distracts from 
more collective, and perhaps more powerful, forms of action, be they defined by consumerism or citizenship. One dimension for evaluating mediated images of citizenship is how passive or engaged they are. Another might be whether the image is of individualistic or collective engagement, a dimension that can be applied to media images of citizens or consumers.

Mass media are widely imagined to only reproduce the available frames in their coverage of issues. While they did reproduce some of the consumer framing of the Medicare reform issue, there were also moments of 'breaking the consumer frame' and raising questions about whether health care might be viewed through the lens of citizenship rather than consumerism, or by considering consumers as a collectivity rather than as atomized individuals. It seems unwise, however, to leave the work of 'breaking the consumer frame' to news media. In the US especially, escalating media concentration is making news organizations leaner and meaner and therefore less inclined to disturb a hospitable selling environment for advertisers or to invest resources in 'thematic coverage' (McChesney 1999, Iyengar 1991). A media system organized around selling things to consumers cannot be relied upon to consistently critique the assumptions of consumerism, or to trumpet the rights of citizenship. As mass media become ever more beholden to advertisers and large corporate owners, we should ask how willing and able they will be to question taken-forgranted assumptions about what it means to be a 'consumer' - of health care, government, or regular products and services. 
Emily West is an Assistant Professor in the Department of Communication at the University of Massachusetts at Amherst.

The author thanks the anonymous reviewers for their valuable feedback, and the College of Social and Behavioral Sciences at the University of Massachusetts at Amherst for a research grant that supported this project. 
i More specifically, the benefit promises a $75 \%$ discount on drugs up to $\$ 2,250$ annually, followed by no benefit until costs of $\$ 5100$ at which point Medicare pays $95 \%$ of drug costs. These discounts are in exchange for a monthly premium estimated to start out at $\$ 37.37 /$ month and a deductible of $\$ 250$, for all but the lowest income seniors. Until January 2006 the government funded prescription drug discount cards estimated to deliver seniors $10-25 \%$ savings on the cost of their drugs. (KFF 2005)

ii The search terms "prescription drug" and "coverage" were used to focus in closely on this issue while excluding the many articles that deal with prescription drugs in other contexts. The term "medicare reform" proved to be too limiting, for example, yielding only 11 articles from USA Today while the actual search terms yielded 57 (some of which were later excluded for not being sufficiently on point).

iii Using N-Vivo, text searches were carried out for the words 'citizen', 'patient', and 'consumer' and their variants, these terms having been judged to be the most prominent and contested in reading the collection of texts. Each instance of the term was examined in context to ensure that it captured the intended use of the term, so 'in-patient' and 'out-patient' were discarded, for example, as they are technical terms rather than voluntary uses of the term 'patient'. Similarly, instances of a term were eliminated when part of a label of a group or organization, or when the word was part of a direct quote.

iv President Bush's three speeches which were broadcast on CNN were counted as a separate category from other CNN reports, and as a source of frames rather than a representation thereof.

v One article was excluded from the AARP corpus for this count because it was explicitly critiquing the idea that more choices are better in health care or other domains. It contained the words 'choice' or 'choices' 26 times, more than all the other AARP documents combined, and therefore was judged to not be representative of AARP discourse. 


\section{$\underline{\text { References }}$}

AARP. 2003a. Statement by AARP CEO Bill Novelli on the need for prescription-drug coverage in Medicare. AARP press center, June 5. http://www.aarp.org/research/ press-center/presscurrentnews/a2003-08-18-needforpd.html

------. 2003b. AARP statement on House passage of Medicare prescription drug bill', AARP press center, November 22. http://www.aarp.org/research/press center/ presscurrentnews/a2003-11-22-rxhousepass.html

ABC News/Washington Post. 2003. Growing health care concerns fuel cautious support for change', Poll vault: ABC News/Washington Post poll archive, October 19, http://abcnews.go.com/images/pdf/935a3HealthCare.pdf.

AHIP. 2003a. AAHP statement on ongoing Medicare negotiations. AHIP press releases, August 26. http://www.ahip.org/content/pressrelease.aspx?docid=177

-------. 2003b. Volunteers launch grassroots Senior Voices for Medicare Choices campaign. AHIP press releases, October 21. http://www.ahip.org/content $\angle$ pressrelease.aspx?docid $=166$

------. 2003c. Enactment of Medicare drug bill honors promise to seniors. AHIP press releases, December 10. downloaded from http://www.ahip.org/content/ pressrelease.aspx?docid $=155$

Bantimaroudis, P. and Ban, H. 2001. Covering the crisis in Somalia: Framing choices by the New York Times and the Manchester Guardian. In Framing public life: Perspectives on media and our understanding of the social world, eds. S.D. Reese, O.H. Gandy Jr., and A.E. Grant, 175-184. Mahwah, NJ: Lawrence Erlbaum Associates.

Barry, P. 2004. Confusion widespread as millions grapple with drug card choices. AARP bulletin online, July-August. http://www.aarp.org/bulletin/prescription/a2004-06-25 pickacard.html

2003. Chasing drugs: many readers take drastic steps to get prescription medicine. AARP bulletin online, October. http://www.aarp.org/bulletin/prescription/Articles La2003-09-29-chasing drugs.html

Breen, T.H. 2004. The marketplace of revolution: How consumer politics shaped American independence. New York: Oxford University Press.

Cappella, J. and Jamieson, K.H. 1997. Spiral of cynicism: The press and the public good. New York: Oxford University Press.

CNN. 2003a. President Bush urges Congress to pass Medicare bill. $\underline{\mathrm{CNN} \text { live }}$ 
event/special, June 28. www.lexis-nexis.com

------. 2003b. President Bush gives weekly radio address. CNN live event/special,

November 22. www.lexis-nexis.com

------. 2003c. President Bush signs Medicare bill. CNN live event/special, December 8. www.lexis-nexis.com

CNN.com. 2003. Medicare overhaul clears Senate. November 25. www.lexis-nexis.com

Cohen, L. 2003. A consumers' republic: The politics of mass consumption in Postwar America. New York: Vintage Books.

Drinkard, J. 2003. Drug bill a well-financed victory for industry. USA Today, July 7, NewsFinal Edition, 4A. www.lexis-nexis.com

Entman, R. 1993. Framing: Toward clarification of a fractured paradigm. Journal of Communication, 43 (3): 51-58.

Families USA. 2004. Cronkite video helps launch national senior education campaign about new Medicare law. Families USA newsroom archives, February 25. http://www.familiesusa.org/site/PageServer?pagename= Media Medicare Road Show Release

------. 2003a. President would force seniors to lose choice of doctors if they want to receive prescription drug coverage. Families USA newsroom archives, January 28. http://www.familiesusa.org/site/PageServer?pagename= State Of The Union Release

------. 2003b. Medicare conference committee may cause significant harm to America's poorest seniors. Families USA newsroom archives, November 22. http://www.familiesusa.org/site/PageServer?pagename= Media Statement Medicare Conference Committee

Findlay, S. 2003. Help both uninsured and seniors, USA Today, February 6, News - Final Edition, 13A.

Gamson, W.A. 2001. Foreword. In Framing public life: Perspectives on media and our understanding of the social world, eds. S.D. Reese, O.H. Gandy Jr., and A.E. Grant, ix-xi. Mahwah, NJ: Lawrence Erlbaum Associates.

------. 1992. Talking politics. New York: Cambridge University Press.

Gandy, O. 1982. Beyond agenda setting: Information subsidies and public policy. Norwood NJ: Ablex Publishing Co.

Gordon, C. 2003. Dead on arrival: The politics of health care in twentieth-century 
America. Princeton, NJ: Princeton University Press.

Iyengar, S. 1991. Is anyone responsible? How television frames political issues.

Chicago: University of Chicago Press.

KFF. 2005. Medicare: the Medicare prescription drug benefit fact sheet. Kaiser Family

Foundation: Medicare, March 14. http://www.kff.org/medicare/upload/7044-02.pdf

------. 2004. Medicare drug discount cards: a work in progress. Kaiser Family Foundation:

Medicare, July 28. http://www.kff.org/medicare/med072804pkg.cfm

Krugman, P. 2005. Free to choose obesity? New York Times, July 8. www.nytimes.com.

Lewis, J., Wahl-Jorgensen, K. and Inthorn, S. 2004. Images of citizenship on television news: Constructing a passive public. Journalism Studies, 5 (2): 153-164.

McChesney, R. 1999. Rich media, poor democracy: Communication politics in dubious times. Urbana, IL: University of Illinois Press.

Miller, M.M. and Reicher, B.P. 2001. The spiral of opportunity and frame resonance: Mapping the issue cycle in news and public discourse. In Framing public life: Perspectives on media and our understanding of the social world, eds. S.D. Reese, O.H. Gandy Jr., and A.E. Grant, 107-122. Mahwah, NJ: Lawrence Erlbaum Associates.

Nightline/ABC News. 2003. Nightline: Critical condition, October 23. www.lexis-nexis.com.

Pan, Z and Kosicki, G.H. 2001. Framing as a strategic action in public deliberation. In Framing public life: Perspectives on media and our understanding of the social world, eds. S.D. Reese, O.H. Gandy Jr., and A.E. Grant, 35-66. Mahwah, NJ: Lawrence Erlbaum Associates.

PhRMA. 2004a. PhRMA praises launch of Medicare retail drug price-comparison Website. PhRMA newsroom, April 29. http://www.phrma.org/actions/ printFriendlyPage.cfm?t $=46 \& \mathrm{r}=987$

------. 2004b. New research shows patients need choice of medicines for best treatment. PhRMA newsroom, August 25. http://www.phrma.org/actions $\angle$ printFriendlyPage.cfm?t=46\&r=1052

-------. 2003. Pharmaceuticals and health care costs: A new debate for a new era. PhRMA newsroom, November 19. http://www.phrma.org/actions/ printFriendlyPage.cfm? $\mathrm{t}=46 \& \mathrm{r}=876$

Putnam, R. 2000. Bowling alone: The collapse and revival of American community. New York: Simon and Schuster.

Richardson, J.D. and Lancendorfer, K.M. 2004. Framing affirmative action: The influence 
of race on newspaper editorial responses to the University of Michigan cases. Press/Politics, 9 (4): 74-94.

Schor, J.B. 2000. Towards a new politics of consumption. In The consumer society reader, eds. J.B. Schor and D.B. Holt, 446-462. New York: The New Press.

Spiker, S. 2004. Health Savings Accounts: Realizing the promise requires educated consumers. AHIP Cover, July-August, 45 (4) 51-52.

Tomes, N. 2003. An undesired necessity: the commodification of medical service in the interwar United States. In Commodifying everything, ed. S. Strasser, 97-114. New York: Routledge 97-114.

------. 2001. Merchants of health: Medicine and consumer culture in the United States. Journal of American History, 88 (2): 519-547. http://www.historycooperative.org /journals/jah/88.2/

Tuchman, G. 1978. Making news. New York: Free Press.

Vaughan, W. 2003. Statement of Families USA before the Subcommittee on Human Rights and Wellness Committee on Government Reform U.S. House of Representatives. Families USA newsroom archives, June 25. http://www.familiesusa.org/resources Lnewsroom/before-the-subcommittee-on-human-rights-and-wellness.html

Welch, W. 2004. Two prescriptions for health insurance crisis. USA Today, October 19, News-Final Edition, 13A. www.lexis-nexis.com

-----. 2003a. GOP takes risk with Medicare overhaul. USA Today, June 16, News Final Edition, 9A. www.lexis-nexis.com

World Health Organization. 2000. The world health report 2000: Health systems: Improving performance. http://www.who.int/whr/2000/en/whr00 en.pdf

World News Tonight-ABC. 2004. Drugs for seniors: Kerry aims comments at seniors. August 11. www.lexis-nexis.com.

------. 2003a. Medicare reform: Medicare bills aim to help seniors. June 28. www.lexis-nexis.com.

------. 2003b. Health care insurance. October 19. www.lexis-nexis.com.

------. 2003c. A closer look: Critical condition. October 20. www.lexis-nexis.com. 
